\title{
Physicochemical Properties of Sugar Industry and Molasses Based Distillery Effluent and its Effect on Water Quality of River Musamya in Uganda
}

\author{
Yonah K. Turinayo
}

National Forestry Resources Research Institute (NaFORRI), National Agricultural Research Organisation (NARO), P. O. BOX 1752, Kampala, Uganda

\begin{abstract}
Despite the economic and ecological importance in terms of supply of water for industrial and domestic use, irrigation and support of aquatic life, River Musamya receives over $1000 \mathrm{~m}^{3}$ of wastewater per day from the nearby sugar industry. However, there is scarcity of information regarding water quality of the River after wastewater discharge. This study determined the physicochemical properties of a sugar industry and molasses based distillery effluent and assessed its effect on water quality of River Musamya. The analysis was conducted between February and April 2010, using standard methods for the examination of water and wastewater. Results showed that pollutant concentrations $(4.3 \mathrm{pH}, 9104 \mathrm{mg}$

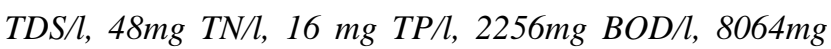
COD/l) of wastewater $(2,523 \pm 728 \mathrm{~m} 3 /$ day $)$ were above permissible limits $(6.0-8.0 \mathrm{pH}, 1200 \mathrm{mg}$ TDS/l, 10mg TN/, 10mg TP/l, 50mg BOD/l, 100mg COD/l) by NEMA. This significantly $(P<0.05)$ altered the water quality downstream the River after discharge. The $\mathrm{pH}, \mathrm{TDS}, \mathrm{T}-\mathrm{Fe}$, $\mathrm{Na}+, \mathrm{Ca} 2+, \mathrm{TN}, \mathrm{TP}$, Turbidity, BOD, COD of the upstream and downstream river after wastewater discharge varied from 7.1 to $5.6,88$ to $1007 \mathrm{mg} / \mathrm{l}, 3.2$ to $10.5 \mathrm{mg} / \mathrm{l}, 5.5$ to $8.0 \mathrm{mg} / \mathrm{l}, 8.5$ to $25 \mathrm{mg} / \mathrm{l}, 1.4$ to $6.8 \mathrm{mg} / \mathrm{l}, 0.8$ to $2.7 \mathrm{mg} / \mathrm{l}, 49$ to $616 \mathrm{NTU}, 3.8$ to $184 \mathrm{mg} / \mathrm{l}, 13$ to $675 \mathrm{mg} / \mathrm{l}$, respectively, and the difference was significant $(P<0.05)$. Therefore, environmental pollution mitigation measures should be put in place to mitigate deterioration of River Musamya's water quality. The sugar industry and distillery should employ technologies that reduce the quantity of wastewater and also install a treatment system that impacts less on the environment.
\end{abstract}

Keywords - Wastewater, Sugar industry, Distillery, Water quality, Molasses.

\section{INTRODUCTION}

The sugar industry in Uganda and the East African Community plays an important role in terms of economic development and improving livelihoods of the surrounding communities. It has demonstrated a high potential of employment opportunities and production of sugar - one of the foods with the highest energy content. Sugar is made in plants and is extracted in a factory. Extraction of sugar begins by processing sugar canes to produce sugar and molasses (by-product). Molasses are further processed in the distillery to produce alcohol.

Despite the socio-economic importance of the sugar industry, there is a high degree of organic pollution load in both aquatic and terrestrial ecosystems as a result of wastewater effluent discharge. This study determined the physico-chemical properties of a sugar industry and molasses based distillery effluent and assessed its effect on water quality of River Musamya. Besides supply of water for industrial and domestic use, irrigation and support of aquatic life, River Musamya acts as a sink of effluent from a nearby sugar industry.

The study was conducted on a privately owned sugar industry located at the fringes of River Musamya in Lugazi town council $\left(1195 \mathrm{~m}\right.$ above sea level, 00 $24^{\prime} \mathrm{N}$ Latitude and $32^{\circ} 56^{\prime}$ E Longitude), Buikwe district. The industry is situated amidst the companies sugar cane plantation covering about 11,000ha including 486ha under forest cover, a sugar plant and a distillery producing over 9 million liters of alcohol per annum. The industry's sugar cane milling rate is over 1,600 tons per day and generates over $1000 \mathrm{~m}^{3}$ of wastewater per day. Though the industry operates stabilization ponds for wastewater treatment, the effluent discharged into the environment is in septic conditions, brownish and with a foul-smell of hydrogen sulfide. This is likely to alter the water quality of any nearby water body [1-3] after discharge.

According to Salequzzaman, et al. [4], the main associated environmental impact of discharge of sugar and distillery wastewater on an open water body is the alteration of its chemistry. This causes fish mortality, serious health hazards to the rural and semi-urban populations $[5,6]$, reduces soil alkalinity and inhibits seed germination [6]. 
Studies [7] have shown that sugar and distillery wastewater effluent contain higher amount of suspended solids, dissolved solids, Biochemical Oxygen Demand (BOD), Chemical Oxygen Demand (COD), chloride sulphate, nitrates, calcium and magnesium, and cause odor nuisance during decomposition. In this study, it is therefore important to assess the levels of pollutants and understand their effect on the environment and recommend appropriate mitigation measures.

Studies on characteristics of wastewater effluents from selected sugar mills and their impact on the growth and biochemical characteristics of terrestrial and aquatic plants have been carried out elsewhere [6, 8, 9]. However, there is scanty of information regarding ecological studies to examine water quality and natural biodiversity of bodies receiving sugar mill effluents in Uganda. More so, little has been done on assessment of quality (eg. dissolved oxygen (DO), BOD and COD) of sugar mill effluent discharged into the environment in Uganda. This study therefore assessed the quality of wastewater effluent from a sugar industry and compared the water quality status before and after effluent discharge into River Musamya.

\section{MATERIALS AND METHODS}

\section{a. Site selection and Sampling}

Sampling regime was designed on the basis of geographical accessibility, location of distillery and sugar processing factory discharges as both join and drain into River Musamya (Fig. 1).

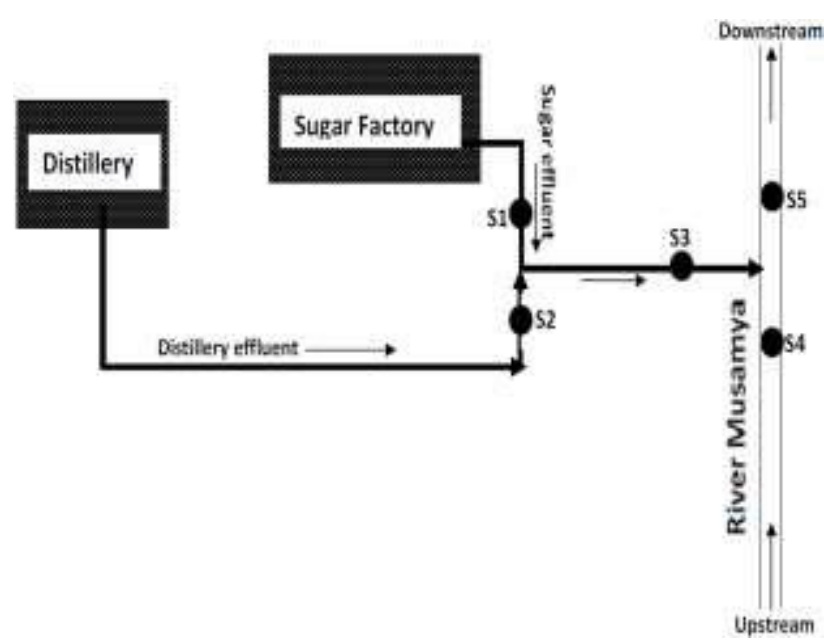

Fig.1: Sampling points along sugar effluent, distillery effluent and River Musamya.

The chosen sampling points were from Sugar Processing Factory and distillery drainage channel (S1 \& S2, respectively), the channel after distillery and factory wastewater effluents have mixed $(50 \mathrm{~m}$ before discharge into the river, S3) and two other sampling points along the river upstream (100m before effluent discharge, S4) and downstream (100m after effluent discharge, S5). Sample collection was done when the factory and distillery were in operation (between 7:00am and 6:00pm) and one sample was picked per point for analysis. Sampling was done twelve times between February and April 2010 in order to get a good representative of the water quality since the operation of the industry was always intermittent. Water samples for laboratory analysis were collected in clean $500 \mathrm{ml}$ plastic bottles, filled to the brim, tightly sealed and kept in a cool box prior to transportation to Water Resource Management Department (WRMD) - Entebbe for analysis of BOD, COD, Turbidity, Total Iron, Na+, $\mathrm{Ca} 2+$, Total Phosphorus, and Total Nitrogen.

\section{b. Water quality analysis}

Water quality parameters (Temperature, pH, electric conductivity, TDS and DO) were measured in situ using Hach Portable Multiparameter Meter (Hach sensION156 portable $\mathrm{pH} /$ conductivity/dissolved oxygen/TDS/ temperature meter) according to manufacturer's instructions. Total nitrogen (TN) and total phosphorus (TP) were determined by cadmium reduction and ascorbic acid methods, respectively [10]. Both TN and TP samples were digested with potassium persulphate and autoclaved for 30 minutes at about $100-110^{\circ} \mathrm{C}$. For digestion of TN samples, potassium persulphate and sodium hydroxide were used simultaneously. Colorimetric determination for TN and TP was by HACH DR 3800 visible spectrophotometer at a wave length of $410 \mathrm{~nm}$ and $660 \mathrm{~nm}$, respectively. Turbidity was measured using $\mathrm{HACH}$ electronic turbidity meter in nephelometric turbidity units (NTU) according to manufacturer's instructions. Chemical oxygen demand (COD) was determined by the dichromate acid digestion method using DR 3800 spectrophotometer, manufactured by HACH LANGE while 5 - day biochemical oxygen demand (BOD) was determined using Winkler's incubation method [10]. Sodium was determined by flame photometer (Model Systronic 128) while calcium and iron were analyzed directly by atomic absorption spectrophotometer (model AA3100, manufactured by Perkin Elmer).

\section{c. Pollution Load Estimation}

Pollution load (kg/day) was determined by multiplying mean pollutant concentration $\left(\mathrm{kg} / \mathrm{m}^{3}\right)$ with the mean effluent discharge ( $\mathrm{m}^{3} /$ day). Mean pollutant concentrations in $\mathrm{mg} / \mathrm{l}$ for TDS, T-Fe, $\mathrm{Na}^{+}, \mathrm{Ca}^{2+}$, TN, TP, BOD, and COD at the point of discharge into River Musamya (sampling point S3) were divided by 1000 to convert to $\mathrm{kg} / \mathrm{m}^{3}$. Effluent discharge $\left(\mathrm{m}^{3} / \mathrm{s}\right)$ was determined using Francis formula (Eqn. 1) in accordance with Perry, et al. [11] for a rectangular sharp-edged weir (Fig. 2).

$$
q=0.415\left(L-0.2 h_{0}\right) h_{0} \sqrt[1.5]{(2 g)}
$$


Where $\mathrm{q}=$ volumetric flow rate $\left(\mathrm{m}^{3} / \mathrm{s}\right), \mathrm{L}=$ crest length, ho = weir head (measured on site), and $\mathrm{g}=$ local acceleration due to gravity $\left(9.81 \mathrm{~m} / \mathrm{s}^{2}\right)$. A factor of 86400 was multiplied by the determined values of volumetric flow rate $\left(\mathrm{m}^{3} / \mathrm{s}\right)$ to convert into $\mathrm{m} 3 /$ day

\section{d. Data analysis}

Data analysis (mean \& standard deviation) was performed using Minitab 16. Differences in each water quality variable between sampling sites were tested using analysis of variance (ANOVA), processed by the Minitab 16 statistics software. Results were considered significant if calculated P-values were $\leq 0.05$.

\section{RESULTS}

The values of physico-chemical parameters of wastewater effluent and water quality of River Musamya after effluent discharge are presented in Table 1 and 2, respectively. The difference in water quality variables of the upstream and downstream river after effluent discharge was highly significant $(\mathrm{P}<0.05)$. The $\mathrm{pH}$ for wastewater discharged into River Musamya was very low and not within permissible limits by National Environment Management Authority (NEMA) as shown in Table 1.

Table.1:Physicochemical characteristics of effluent from sugar industry and molasses based distillery (Mean \pm standard deviation, $n=12$ )

\begin{tabular}{|c|c|c|c|c|}
\hline Variable & $\mathbf{S}_{1}$ & $\mathbf{S}_{\mathbf{2}}$ & $\mathbf{S}_{3}$ & $\begin{array}{l}\text { permissible } \\
\text { limits [12] }\end{array}$ \\
\hline pH & $\begin{array}{ll}4.2 & \pm \\
0.2 & \end{array}$ & $\begin{array}{ll}3.8 & \pm \\
0.2 & \end{array}$ & $4.3 \pm 0.1$ & $6.0-8.0$ \\
\hline TDS (mg/l) & $\begin{array}{l}3142 \\
\pm \\
1149\end{array}$ & $\begin{array}{l}15104 \pm \\
5098\end{array}$ & $\begin{array}{l}9104 \\
2833\end{array}$ & 1200 \\
\hline $\mathrm{EC}(\boldsymbol{\mu s} / \mathbf{c m})$ & $\begin{array}{l}4697 \\
\pm \\
1564\end{array}$ & $\begin{array}{l}19361 \\
\pm 7046\end{array}$ & $\begin{array}{l}10089 \\
\pm 3722\end{array}$ & 1500 \\
\hline T Fe (mg/l) & $\begin{array}{l}44.8 \pm \\
8.8\end{array}$ & $\begin{array}{l}65.6 \pm \\
19.8\end{array}$ & $61.9 \pm 12.3$ & 10 \\
\hline $\mathrm{Na}^{+}(\mathrm{mg} / \mathrm{l})$ & $\begin{array}{l}40.7 \pm \\
7.8\end{array}$ & $\begin{array}{l}42.8 \pm \\
12.0\end{array}$ & $31.3 \pm 8.5$ & * \\
\hline $\mathrm{Ca}^{2+}(\mathrm{mg} / \mathrm{l})$ & $\begin{array}{l}79 \pm \\
15\end{array}$ & $\begin{array}{l}175 \quad \pm \\
30\end{array}$ & $126 \pm 18$ & 100 \\
\hline TN (mg/l) & $\begin{array}{l}41 \pm \\
10\end{array}$ & $71 \pm 14$ & $48 \pm 10$ & 10 \\
\hline $\mathbf{T P}(\mathrm{mg} / \mathrm{l})$ & $20 \pm 8$ & $18 \pm 4$ & $16 \pm 4$ & 10 \\
\hline Turbidity(NTU) & $\begin{array}{l}2940 \pm \\
1492\end{array}$ & $\begin{array}{l}6531 \pm \\
2584\end{array}$ & $\begin{array}{l}4774 \\
1851\end{array}$ & 300 \\
\hline $\operatorname{Temp}\left({ }^{\circ} \mathrm{C}\right)$ & $\begin{array}{l}30.7 \pm \\
0.6\end{array}$ & $\begin{array}{l}25.8 \quad \pm \\
0.4\end{array}$ & $27.3 \pm 0.3$ & $20-30$ \\
\hline BOD (mg/l) & $\begin{array}{l}1295 \\
\pm 569\end{array}$ & $\begin{array}{l}4723 \pm \\
1242\end{array}$ & $2256 \pm 820$ & 50 \\
\hline
\end{tabular}

$\begin{array}{llll}3821 & 16152 & 8064 \pm 2250 & 100 \\ \pm & \pm 4109 & & \\ 1229 & & & \\ 0.19 \pm & 0.14 \pm & 0.25 \pm 0.03 \\ 0.02 & 0.03 & & *\end{array}$

$\mathrm{S}_{1}=$ sugar processing wastewater; $\mathrm{S}_{2}=$ distillery wastewater; $\mathrm{S}_{3}=$ mixed distillery and sugar processing wastewater. *missing values. discharge

After effluent discharge into the River, there was a significant decrease $(\mathrm{P}=0.000)$ in $\mathrm{pH}$ of water downstream (Table 2). The lowest values of $\mathrm{pH}(3.8 \pm 0.2$; Table 1) were detected from distillery effluents.

The Total dissolved solids (TDS) and Electrical conductivity (EC) values $(9104 \pm 2833 \mathrm{mg} / \mathrm{l}$ and 10089 $\pm 3722 \mu \mathrm{s} / \mathrm{cm}$, respectively) of wastewater discharged into River Musamya at point S3 were very high and deviated from NEMA standards $(1200 \mathrm{mg} / 1$ and $1500 \mu \mathrm{s} / \mathrm{cm}$, respectively) for wastewater discharge into the environment (Table 1). After discharge into the river, there was a significant increase $(\mathrm{p}=0.002)$ in TDS values of downstream water from $88 \pm 15$ to $1007 \pm 262$ (Table 1 ).

The TDS values in distillery wastewater were significantly ( $\mathrm{p}=0.032$ ) higher than those in sugar processing wastewater. Electrical Conductivity and Total Dissolved Solids values depicted a linear relationship (Pearson correlation coefficient $=0.965$ ) and after effluent discharge into River Musamya, EC of downstream river water significantly $(\mathrm{p}=0.007)$ increased.

Turbidity of river water downstream (after effluent discharge) was significantly $(\mathrm{p}=0.014)$ higher than upstream river water (before effluent discharge). There was no significant difference between turbidity of distillery wastewater and sugar processing wastewater $(\mathrm{p}=$ 0.242). However, mean turbidity values (4774 \pm 1851NTU) of effluent discharge into River Musamya did not conform to the NEMA standard (300NTU) for wastewater discharge (Table 1).

Table.2: Quality of water in River Musamya before and after effluent discharge (the difference was significant, $p<$ 0.05); Mean \pm standard deviation, $n=12$

\begin{tabular}{|c|c|c|c|}
\hline & $\mathbf{S}_{4}$ & $\mathbf{S}_{5}$ & $\begin{array}{l}\text { permissible } \\
\text { limits [12] }\end{array}$ \\
\hline pH & $\begin{array}{ll}7.07 & \pm \\
0.01 & \end{array}$ & $5.6 \pm 0.2$ & $6.0-8.0$ \\
\hline TDS (mg/l) & $88 \pm 15$ & $1007 \pm 262$ & 1200 \\
\hline $\mathrm{EC}(\boldsymbol{\mu s} / \mathbf{c m})$ & $108 \pm 32$ & $1524 \pm 472$ & 1500 \\
\hline T Fe (mg/l) & $3.2 \pm 0.4$ & $10.5 \pm 1.4$ & 10 \\
\hline $\mathrm{Na}^{+}(\mathrm{mg} / \mathrm{l})$ & $5.5 \pm 0.7$ & $8.0 \pm 1.0$ & $*$ \\
\hline $\mathrm{Ca}^{2+}(\mathrm{mg} / \mathrm{l})$ & $8.5 \pm 0.8$ & $25 \pm 4$ & 100 \\
\hline TN (mg/l) & $1.4 \pm 0.3$ & $6.8 \pm 1.5$ & 10 \\
\hline $\mathbf{T P}(\mathrm{mg} / \mathrm{l})$ & $0.8 \pm 0.2$ & $2.7 \pm 0.7$ & 10 \\
\hline Turbidity(NTU) & $49 \pm 8$ & $616 \pm 212$ & 300 \\
\hline
\end{tabular}




\begin{tabular}{lllll}
\hline Temp $\left({ }^{\circ} \mathbf{C}\right)$ & 24.8 & \pm & $25.7 \pm 0.2$ & $20-30$ \\
& 0.2 & & \\
BOD $(\mathbf{m g} / \mathbf{l})$ & $3.8 \pm 1.1$ & $184 \pm 43$ & 50 \\
COD $(\mathbf{m g} / \mathbf{l})$ & $13 \pm 4$ & $675 \pm 70$ & 100 \\
DO $(\mathbf{m g} / \mathbf{l})$ & $6.50 \quad \pm$ & $2.83 \pm 0.29$ & $*$ \\
& 0.30 & &
\end{tabular}

$\mathrm{S}_{4}=$ upstream river water; $\mathrm{S}_{5}=$ downstream river water; *missing values

The mean wastewater temperature values $\left(27.3 \pm 0.3^{\circ} \mathrm{C}\right)$ for all sampling points were within NEMA permissible limits $\left(20-30^{\circ} \mathrm{C}\right)$ for wastewater discharge into the environment (Table 1). However, there was a significant increase $(\mathrm{p}=0.004)$ in river water temperature after effluent discharge (Table 2). It was discovered that sugar processing generated wastewater with temperature significantly higher $(\mathrm{p}=0.005)$ than that of distillery wastewater $\left(30.7 \pm 0.6\right.$ and $25.8 \pm 0.4^{\circ} \mathrm{C}$, respectively).

Both the sugar industry and molasses based distillery generated wastewater with high values of BOD (2256 \pm $820 \mathrm{mg} / \mathrm{l})$ and COD $(8064 \pm 2250 \mathrm{mg} / \mathrm{l})$, and low DO $(0.25$ $\pm 0.03 \mathrm{mg} / \mathrm{l})$ concentrations, which were outside NEMA permissible limits for wastewater discharge (50mg/l BOD and 100mg/l COD; Table 1). After discharge into River Musamya, there was a significant difference between BOD and COD concentrations in upstream and downstream river water $(\mathrm{p}<0.001)$, while the average DO concentration significantly $(\mathrm{p}=0.000)$ decreased from $6.50 \pm 0.30 \mathrm{mg} / 1$ to $2.83 \pm 0.29 \mathrm{mg} / 1$ (Table 2 ). Results further showed that the distillery generated wastewater of higher BOD $(\mathrm{p}=0.02)$ and COD $(\mathrm{p}=0.009)$ levels than the sugar processing.

Mean values of Total Nitrogen (TN) and Total Phosphorus (TP) concentrations $(48 \pm 10 \mathrm{mg} / \mathrm{l}$ and $16 \pm 4 \mathrm{mg} / \mathrm{l}$, respectively) of effluent discharged into River Musamya were determined (Table 1 and Figure 1). It was observed that there was a significant increase in concentrations of $\mathrm{TN}(\mathrm{p}=0.002)$ and TP $(\mathrm{p}=0.010)$ in the river water, from $1.4 \pm 0.3 \mathrm{mg} / \mathrm{l}$ to $6.8 \pm 1.5 \mathrm{mg} / \mathrm{l}$ and $0.8 \pm 0.2 \mathrm{mg} / 1$ to $2.7 \pm$ $0.7 \mathrm{mg} / \mathrm{l}$, respectively, after the discharge of wastewater. Total phosphorus and TN concentrations in effluent were outside NEMA permissible limits $(10 \mathrm{mg} / \mathrm{l})$ for discharge into the environment. Results (Table 1 and Figure 3) show that concentrations of $\mathrm{TN}$ were higher than $\mathrm{TP}$ at all sampling points. However, there were no significant differences detected between concentrations of TP ( $\mathrm{p}=$ $0.878)$ and $\mathrm{TN}(\mathrm{p}=0.105)$ in sugar processing and in distillery wastewater.

Concentrations of total iron (T-Fe, $61.9 \pm 12.3 \mathrm{mg} / \mathrm{l}), \mathrm{Na}^{+}$ $(31.3 \pm 8.5 \mathrm{mg} / \mathrm{l})$ and $\mathrm{Ca}^{2+}(126 \pm 18 \mathrm{mg} / \mathrm{l})$ detected in wastewater were also outside discharge NEMA standards $\left(10 \mathrm{mg} / \mathrm{l} \mathrm{Na}^{+}\right.$and $100 \mathrm{mg} / \mathrm{l} \mathrm{Ca}^{2+}$ ) (Table 1). As depicted in Figure 3 , it was observed that concentrations of $\mathrm{Ca}^{2+}$, T-Fe and $\mathrm{Na}^{+}$followed a trend of $\mathrm{Ca}^{2+}>\mathrm{T}-\mathrm{Fe}>\mathrm{Na}^{+}$in the mixed distillery and sugar processing wastewater and river water downstream after effluent discharge.

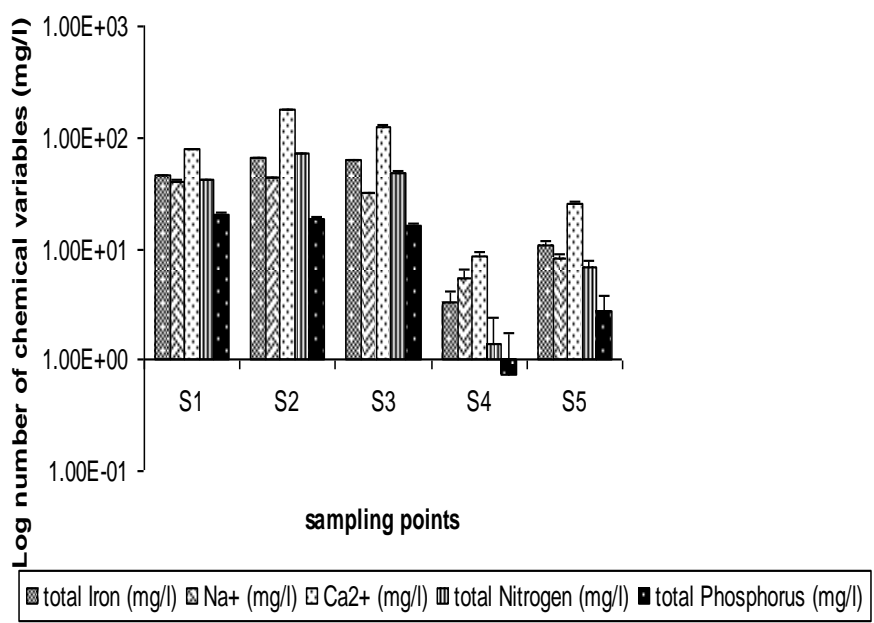

Fig.3: Mean concentrations of inorganic pollutants in sugar processing effluent, distillery effluent and $R$.

Musamya water

There was a significant increase in concentrations of $\mathrm{Ca}^{2+}$ $(\mathrm{p}=0.001)$, total iron $(\mathrm{p}<0.001)$ and $\mathrm{Na}^{+}(\mathrm{p}=0.043)$ from about $8.5 \mathrm{mg} / \mathrm{l}$ to $25 \mathrm{mg} / 1,3.2 \mathrm{mg} / 1$ to $10.5 \mathrm{mg} / \mathrm{l}$ and $5.5 \mathrm{mg} / 1$ to $8.0 \mathrm{mg} / \mathrm{l}$, respectively in the river water downstream after discharge of wastewater effluent. $\mathrm{Ca}^{2+}$ concentrations in sugar processing wastewater (175 \pm $30 \mathrm{mg} / \mathrm{l})$ was significantly higher $(\mathrm{p}=0.008)$ than in distillery wastewater $(79 \pm 15 \mathrm{mg} / \mathrm{l})$, as detected by oneway ANOVA. When wastewater with high total iron, $\mathrm{Ca}^{2+}$, $\mathrm{Na}^{+} \mathrm{TN}, \mathrm{TP}, \mathrm{EC}$ and TDS values was discharged into River Musamya, it altered the quality of the river water downstream significantly ( $\mathrm{p}<0.05$ ).

Results of pollution load from both sugar industry and molasses based distillery into River Musamya are depicted in Table 3. It was observed that there was high pollution load (kg/day) of TDS, COD and BOD (22970 \pm 8453 , $20346 \pm 4449$ and $5692 \pm 1666$, respectively) into the river compared to T-Fe, $\mathrm{Na}^{+}, \mathrm{Ca}^{2+}$, TN and TP $(156 \pm 35,68 \pm$ $19,319 \pm 49,121 \pm 29$ and $40 \pm 14$, respectively).

Table.3: Mean pollution load ( $\mathrm{kg} /$ day) discharged in River

\begin{tabular}{ll}
\multicolumn{2}{c}{ Musamya $(n=12)$} \\
\hline Variable & $\mathbf{S}_{\mathbf{3}}$ \\
\hline $\mathrm{TDS}$ (kg/day) & $22970 \pm 8453$ \\
$\mathrm{~T}-\mathrm{Fe}$ (kg/day) & $156 \pm 35$ \\
$\mathrm{Na}^{+}$(kg/day) & $68 \pm 19$ \\
$\mathrm{Ca}^{2+}$ (kg/day) & $319 \pm 49$ \\
$\mathrm{TN}$ (kg/day) & $121 \pm 29$ \\
$\mathrm{TP}$ (kg/day) & $40 \pm 14$ \\
$\mathrm{BOD}$ (kg/day) & $5692 \pm 1666$ \\
$\mathrm{COD}$ (kg/day) & $20346 \pm 4449$
\end{tabular}


Discharge $\left(\mathrm{m}^{3} /\right.$ day $) \quad 2523 \pm 728$

$\mathbf{S}_{\mathbf{3}}=$ Sampling point were distillery and sugar processing wastewater is mixed before discharge into River Musamya

\section{DISCUSSION OF RESULTS}

The $\mathrm{pH}$ values in this study were in line with the work of other authors [13-15] who found the $\mathrm{pH}$ of distillery wastewater relatively acidic $(3.3-3.9$ and $3.8-4.5$, respectively). The low $\mathrm{pH}$ of the distillery effluent is due to the presence of higher concentration of organic acids such as $\mathrm{CH} 3 \mathrm{COOH}$ formed during biochemical conversion of highly biodegradable organic matter [16, 17] resulting from high BOD and COD loading (Table 3). Doke, et al. [6] found the $\mathrm{pH}$ in sugar process effluent to be 4.35 which was close to that of the present study (Table 1). The acidity of sugar processing wastewater was possibly due to the use of phosphoric acid and sulfur dioxide during clarification of sugar cane juice [6]. However, the acidic nature of the downstream river water was attributed to the discharge of large volumes of acidic wastewater $(2523 \pm 728 \mathrm{~m} 3 / \mathrm{day} ; \mathrm{pH}$ $4.3 \pm 0.1)$.

The high values of electrical conductivity and total dissolved solids recorded from both distillery and sugar processing wastewater could be attributed to high levels of total iron, $\mathrm{Ca}^{2+}, \mathrm{Na}^{+} \mathrm{TN}$ and TP as shown in Tables 1 and 3. High turbidity values were probably due to mud and molasses from sugar processing and large volumes of spent wash from distillery [2, 7].

The high values of biochemical oxygen demand (BOD) and chemical oxygen demand (COD) could have been due to distillery spent wash from fermented molasses, spillages of molasses and juice from sugar processing which are organic in nature $[1,3,18]$. After discharge of the effluent into River Musamya, the average DO concentration downstream dropped from $6.5 \pm 0.3$ to $2.8 \pm 0.3 \mathrm{mg} / \mathrm{l}$, due to high load of oxygen-consuming organic pollutants (Tables 3$)$ and a significant rise $(p=0.004)$ in temperature of polluted river water. This is in conformity with the study by Salequzzaman, et al. [4] who found out that solubility of oxygen decreases with an increase in temperature, and effluent with high BOD and COD accelerates bacterial growth in the river; hence reduce the dissolved oxygen levels.

High values of $\mathrm{TN}$ and $\mathrm{TP}$ in effluent could be due to nitrogenous (nitrogen, Asparagine, Glutamine, Aspartic) and phosphate $\left(\mathrm{P}_{2} \mathrm{O}_{5}\right.$, phosphoric acid) matter found in sugar cane juice [19]. These compounds come along with sugar cane from plantation and find their way into molasses and mud after sugar process, then later in wastewater. On the other hand, nitrogen and phosphate are introduced in sugar cane plantations as fertilizers to boost its growth.

High concentration of $\mathrm{Ca}^{2+}$ are due to lime spill during sugarcane processing (about 2.25 tons of lime is used per day for juice clarification and raising the $\mathrm{pH}$ of condenser water). In contrast, there was no significant difference between total iron $(\mathrm{p}=0.348)$ and $\mathrm{Na}^{+}(\mathrm{p}=0.819)$ in sugar processing wastewater $(65.6 \pm 19.8 \mathrm{mg} / \mathrm{l}$ and $42.8 \pm$ $12.0 \mathrm{mg} / \mathrm{l}$, respectively) and in distillery wastewater $(44.8 \pm$ $8.8 \mathrm{mg} / 1$ and $40.7 \pm 7.8 \mathrm{mg} / 1$, respectively). High concentration of total iron could probably be due to hydrated iron III oxide, as a result of corrosion of metallic equipments both in distillery and sugar processing, since most of the liquid materials handled are acidic. However, run-off of nutrients (in form of fertilizers) from the plantation field and sediments due to soil erosion could have also contributed to high load of TN, TP, Total Iron, $\mathrm{Ca}^{2+}, \mathrm{Na}^{+}$and TDS into River Musamya.

\section{CONCLUSION}

Despite the sugar industry being economically important, the effect of its effluent wastewaters on the environment is significant. River Musamya received wastewater with a high organic matter and nutrient load and the difference in water quality variables of the upstream and downstream river after wastewater discharge was highly significant. Sugar industries and distilleries should therefore employ technologies that reduce the quantity of waste effluents generated and install a wastewater treatment system that impacts less on the environment. Further studies should also be conducted on the impact of sugar plant operations on the general ecology of River Musamya.

\section{ACKNOWLEDGEMENTS}

This study was supported by SCOUL and the Water Resource Management Department (WRMD) -Entebbe in providing the conducive environment for water quality analysis. The decision to submit this article for publication was entirely made by the author; SCOUL and WRMD take no responsibility of any kind. The author extends his sincere appreciation to these institutions for their support. Special thanks go to Dr. Joseph Kyambadde and Dr. Robinson Odong for the supervision of this work.

\section{REFERENCES}

[1] K. Rajeshwari, M. Balakrishnan, A. Kansal, K. Lata, and V. Kishore, "State-of-the-art of anaerobic digestion technology for industrial wastewater treatment," Renewable and Sustainable Energy Reviews, vol. 4, pp. 135-156, 2000.

[2] N. Jain, A. Bhatia, R. Kaushik, S. Kumar, H. Joshi, and H. Pathak, "Impact of post-methanation distillery 
effluent irrigation on groundwater quality," Environmental monitoring and assessment, vol. 110, pp. 243-255, 2005.

[3] D. Pant and A. Adholeya, "Biological approaches for treatment of distillery wastewater: a review," Bioresource technology, vol. 98, pp. 2321-2334, 2007.

[4] M. Salequzzaman, S. T. Islam, A. Tasnuva, M. Kashem, and M. Masud, "Environmental impact of sugar industry a case study on Kushtia sugar mills in Bangladesh," J Innov Dev Strat, vol. 2, pp. 31-35, 2008.

[5] G. Gunkel, J. Kosmol, M. Sobral, H. Rohn, S. Montenegro, and J. Aureliano, "Sugar cane industry as a source of water pollution-Case study on the situation in Ipojuca River, Pernambuco, Brazil," Water, Air, and Soil Pollution, vol. 180, pp. 261-269, 2007.

[6] K. M. Doke, E. M. Khan, J. Rapolu, and A. Shaikh, "Physico-chemical analysis of sugar industry effluent and its effect on seed germination of Vigna angularis, Vigna cylindri," 2011.

[7] P. Saranraj and D. Stella, "Impact of sugar mill effluent to environment and bioremediation: a review," World Appl Sci J, vol. 30, pp. 299-316, 2014.

[8] P. M. Ayyasamy, R. Yasodha, S. Rajakumar, P. Lakshmanaperumalsamy, P. Rahman, and S. Lee, "Impact of sugar factory effluent on the growth and biochemical characteristics of terrestrial and aquatic plants," Bulletin of environmental contamination and toxicology, vol. 81, pp. 449-454, 2008.

[9] U. Damodharan and M. V. Reddy, "Impact of Sugar Industrial Treated Effluent on the Growth Factor in Sugarcane-Cuddalore, India," Journal of Sustainable Bioenergy Systems, vol. 2, p. 43, 2012.

[10] W. E. Federation and A. P. H. Association, "Standard methods for the examination of water and wastewater," American Public Health Association (APHA): Washington, DC, USA, 2005.

[11] R. H. Perry, D. W. Green, and J. O. Maloney, "Perry's chemical engineers' handbook. 7th," McGrow-Hill, New York, 1997.

[12] NEMA, "Environmental standards and preliminary environmental impact assessment for water quality and discharge of effluent into water and land in Uganda " in National Environment Management Authority (NEMA), Ministry of Natural Resources, , ed. Kampala: Government of the Republic of Uganda, 1999.

[13] B. B. Nalukowe, Sustainable Industrial Development in Uganda Through Cleaner Production: Case Study of Sugar Corporation of Uganda Ltd (SCOUL): Industrial Ecology, Royal Institute of Technology, 2006.

[14] G. S. Kumar, S. Gupta, and G. Singh, "Biodegradation of distillery spent wash in anaerobic hybrid reactor," Water research, vol. 41, pp. 721730, 2007.

[15] S. Jiranuntipon, M. Delia, C. Albasi, S. Damronglerd, S. Chareonpornwattana, J. Thaniyavarn, et al., "Decolourization of molasses based distillery wastewater using a bacterial consortium," Science Asia, vol. 35, pp. 332-339, 2009.

[16] R. Ale, P. Jha, and N. Belbase, "Effect of distillery effluent on some agricultural crops, a case of environmental injustice to local farmers in Khajura VDC, Banke," Scientific world, vol. 6, pp. 68-75, 2008.

[17] M. M. Theron and J. F. R. Lues, Organic acids and food preservation: Taylor \& Francis, 2011.

[18] A. Ryznar-Luty, M. Krzywonos, E. Cibis, and T. Miśkiewicz, "Aerobic Biodegradation of Vinasse by a Mixed Culture of Bacteria of the Genus Bacillus: Optimization of Temperature, $\mathrm{pH}$ and Oxygenation State," Polish Journal of Environmental Studies, vol. 17, 2008.

[19] C. C. Thai and W. O. Doherty, "The composition of sugarcane juices dervied from burnt cane and whole green cane crop," in Proceedings of the 33rd Annual Conference of the Australian Society of Sugar Cane Technologists 2011, 2011, pp. 368-376. 